Finance and Economics Discussion Series

Divisions of Research \& Statistics and Monetary Affairs

Federal Reserve Board, Washington, D.C.

\title{
Explaining Cyclical Movements in Employment: Creative Destruction or Changes in Utilization
}

\begin{abstract}
Andrew Figura
2006-23

NOTE: Staff working papers in the Finance and Economics Discussion Series (FEDS) are preliminary materials circulated to stimulate discussion and critical comment. The analysis and conclusions set forth are those of the authors and do not indicate concurrence by other members of the research staff or the Board of Governors. References in publications to the Finance and Economics Discussion Series (other than acknowledgement) should be cleared with the author(s) to protect the tentative character of these papers.
\end{abstract}




\title{
Explaining Cyclical Movements in Employment: Creative-Destruction or Changes in Utilization?
}

\author{
Andrew Figura*
}

May, 2006

JEL Classification: J23, E24

Keywords: Cyclical Employment Changes, Permanent and Temporary Employment Changes

\begin{abstract}
An important step in understanding why employment fluctuates cyclically is determining the relative importance of cyclical movements in permanent and temporary plant-level employment changes. If movements in permanent employment changes are important, then recessions are times when the destruction of job specific capital picks up and/or investment in new job capital slows. If movements in temporary employment changes are important, then employment fluctuations are related to the temporary movement of workers across activities (e.g. from work to home production or search and back again) as the relative costs/benefits of these activities change. I estimate that in the manufacturing sector temporary employment changes account for approximately 60 percent of the change in employment growth over the cycle. However, if permanent employment changes create and destroy more capital than temporary employment changes, then their economic consequences would be relatively greater. The correlation between gross permanent employment changes and capital intensity across industries supports the hypothesis that permanent employment changes do create and destroy more capital than temporary employment changes.
\end{abstract}

*Mail Stop 80, Board of Governors of the Federal Reserve System, Washington DC 20551. Email: jfigura@frb.gov. The research in this paper was conducted while the author was a Special Sworn Status researcher of the U.S. Census Bureau at the Center for Economic Studies. Research results and conclusions expressed are those of the authors and do not necessarily reflect the views of the Census Bureau, the Federal Reserve Board or their staffs. This paper has been screened to insure that no confidential data are revealed. 


\section{Introduction}

Understanding why employment varies cyclically is important for understanding both the origins of business cycles and the welfare implications of fluctuations in the pace of economic activity. An important step in understanding why employment fluctuates cyclically is determining the relative importance of cyclical movements in permanent and temporary plantlevel employment changes. If movements in permanent employment are important, then recessions are times when the destruction of job specific capital (physical, human and organizational) picks up and/or investment in new job capital slows. Understanding how incentives to destroy or create this capital change over the cycle is then key to understanding the timing, duration and magnitude of cyclical fluctuations. ${ }^{1}$ If movements in temporary employment changes are important, then employment fluctuations are related to the temporary movement of workers across activities (e.g. from work to home production or search and back again) as the relative costs/benefits of these activities change. In this case, understanding why and how the relative attractiveness of these alternative activities changes becomes key to understanding the change in employment growth over the cycle. ${ }^{2}$

Both permanent and temporary employment changes can be efficient or inefficient, but the type of inefficiency and any policy needed to address it likely differ across these two kinds of employment changes. Caballero and Hammour (1996) show that whether cyclical swings in the permanent creation and destruction of jobs is inefficiently too large or too small depends importantly on the size of the sunk costs of permanent job creation. Such costs are unimportant

\footnotetext{
${ }^{1}$ Papers that discuss cyclical fluctuations in permanent plant-level employment changes include Caballero and Hammour (1994,1996), Mortensen and Pissarides (1994) and Davis and Haltiwanger (1990).

${ }^{2}$ Papers that discuss cyclical fluctuations in temporary plant-level employment changes include: those describing the intertemporal substitution of labor when wage insurance is provided by employers, e.g. Bailey (1974) and Azariadis (1975); those discussing the unresponsiveness of wages to changes in cyclical demand, e.g. Hall and Lazear (1984), Akerlof and Yellen (1990) and Solow and MacDonald (1980); and those describing temporary movements of workers across sectors, including home production, e.g. Barlevy (2001) and Benhabib, Rogerson and Wright (1991).
} 
when considering the inefficiency of temporary employment changes, which are affected, instead, by policies and/or institutions that drive a wedge between the returns to work or home production and the marginal products of these activities. For example, Feldstein (1976) shows that UI benefits can lead to inefficiently low levels of market work by providing too strong an incentive to change from work to other activities in response to temporary changes in the marginal revenue product of market work.

Estimation of permanent and temporary plant-level employment changes requires a data set with sufficiently long time series of plant-level employment. I use the Census Bureau's Longitudinal Record Data set (LRD), which satisfies this requirement for a large number of manufacturing plants. To isolate permanent changes in employment at continuing plants, I apply a low pass filter to time series of plant-level employment. To estimate permanent plant shutdowns and startups, I use the methodology of Davis, Haltiwanger and Schuh (1996), henceforth DHS. Combining permanent shutdowns and startups with permanent and temporary employment changes of continuous plants yields aggregate rates of permanent and temporary employment changes.

I estimate that temporary employment changes account for about sixty percent of annual plant-level employment changes in the manufacturing sector, with permanent employment changes accounting for the remaining forty percent. Temporary employment changes account for a similar proportion of the change in employment growth over the cycle. Thus, both types of employment changes contribute importantly to cyclical movements in employment, though the contribution of temporary employment changes is greater.

However, to the extent that the economic consequences of the two types of employment changes are different, their relative importance may be different than simple tabulations of their 
cyclical variation suggest. In particular, it seems likely that permanent employment changes entail the creation and destruction of more specific capital (physical, organizational and human), than temporary employment changes. A simple model of permanent and temporary employment changes suggests a test of this hypothesis. The model predicts that permanent employment changes should be smallest in industries with high sunk costs of job creation, or greater amounts of specific capital per job. When sunk costs are high, plants will be more hesitant to respond to changes in demand by permanent job creation. In addition, because sunk costs raise the option value of maintaining jobs after a plant has suffered an adverse relative productivity/demand shock, permanent job destruction will also be less responsive to shocks. Put another way, the amount of permanent job flows should be inversely proportional to its costs. Cross industry regressions using capital intensity as a proxy for the level of sunk costs confirm the model's prediction.

Putting these results together, though temporary plant-level employment changes account for more of the cyclical fluctuation in employment than permanent plant-level employment changes, permanent employment changes are more costly and have potentially greater economic consequences. As a result, both creative destruction and changing utilization are important aspects of cyclical fluctuations.

Many papers have investigated the behavior of plant-level employment changes, but few have tried to identify temporary and permanent employment changes, and none that I am aware of have sought to distinguish the economic consequences of these two types of employment changes or to quantify their relative importance to cyclical changes in aggregate employment. DHS, among others, estimate plant shutdowns and startups. In addition, they construct measures of persistent job changes at continuing plants. However, they consider only forward persistence 
(whether an employment change in period $t$ will be reversed in periods $t+1, t+2$, etc), not backward persistence (whether an employment change in period $t$ reverses an employment changes in periods $t-1, t-2$, etc.). Moreover, their choice of method does not make clear what level of persistence should be associated with plant-level employment changes not directly related to business cycle fluctuations in utilization. Finally, they only report their most persistent measure of employment changes ( 2 years) for a limited number of years making analysis of changes in permanent flows over the business cycle problematic. In my measures of permanent employment changes, I use a method similar to that of DHS to identify shutdowns and startups but add an additional filter to distinguish between permanent and temporary shutdowns and startups. For continuous plants, the low pass filter I use isolates employment changes that are long-lasting from both a forward and backward perspective. In addition, I choose weights for the low pass filter that identify permanent employment flows as having a frequency lower than that associated with business cycles. Finally, I measure the contributions to cyclical employment movements of permanent and temporary employment changes and test whether the two types of employment changes have different economic consequences.

The following section describes in more detail the data and method I use to distinguish permanent and temporary employment changes. Section 3 reports measures of the magnitudes and cyclical movements of both temporary and permanent changes in employment. Section 4 builds a simple model of permanent and temporary changes in employment and tests its predictions regarding the cross industry correlation between the frequency of permanent changes and the sunk costs of job capital. Section 5 concludes. 


\section{Measuring Permanent and Temporary Employment Changes}

To estimate permanent employment changes I combine estimates of long-lasting increases and decreases in employment at continuing plants with permanent plant startups and shutdowns. To estimate the former, I use a low pass filter developed by Baxter and King (1999). The filter removes fluctuations in employment that are temporary in duration, while preserving those changes that are long lasting. To estimate the latter, I modify slightly the methodology of DHS.

As shown by Baxter and King (1999) a low pass filter can be implemented by taking a centered symmetric weighted moving average of a time series, where weights are determined by restrictions in the frequency domain. The ideal filter is an infinite order moving average. Of course, construction of such a filter is not possible, and researchers must pay for increases in the accuracy of the filter with decreases in sample size. Baxter and King examine this trade-off and recommend using a centered window of 7 years when researchers are concerned about separating business cycle-related fluctuations from longer-lasting movements. Implementation of the filter also requires specification of a cutoff period/frequency to separate low from high frequency movements in the series. Baxter and King recommend a cut-off of 8 years to filter out movements related to business cycles, and I follow their recommendation. I apply the resulting low pass filter to annual data on total employment (production workers plus nonproduction workers) which is available at an annual frequency from the LRD.

The LRD derives from the quinquennial Census of Manufacturers (CM) and the Annual Survey of Manufacturers (ASM). The CM gathers data on all plants in the manufacturing sector, approximately 350,000, while the ASM gathers data from a representative sample of 50,000 to 80,000 plants. Large plants (generally those with employment greater than 250) are selected 
with certainty to be in the ASM, while small plants are selected randomly. Because the LRD assigns plants a unique identification number that does not change over time, I can create plantlevel time series of employment. For plants with sufficiently long time series centered on period $t$, I apply a low pass filter to estimate the permanent and temporary (the difference between actual and permanent) levels of employment for the plant at time $t$. Summing across those plants produces measures of aggregate permanent and temporary employment at time $t$, and differencing the data for all plants with permanent and temporary employment levels in $t$ and $t-1$ yields aggregate permanent and temporary job flows from $t-1$ to $t$.

The number of plants with employment histories long enough to estimate permanent employment varies from year to year, causing breaks in the levels of aggregate employment unrelated to plant-level employment changes. ${ }^{3}$ To eliminate the changes in employment introduced by this effect, I focus on rates of permanent and temporary employment changes. With data from the LRD on plant-level employment from 1972 to 1996, I can estimate rates of permanent and temporary plant-level job flows for the manufacturing sector from 1976 to $1993 .{ }^{4}$

I compute rates of gross and net changes in permanent and temporary employment using the definition of job flows in DHS. Specifically, gross rates of permanent and temporary employment changes are estimated as

$$
\operatorname{Gross}_{t}^{c, k}=\sum_{i \in c}\left(\frac{2 a b s\left(e_{i, t}^{k}-e_{i, t-1}^{k}\right)}{\left(e_{i, t}+e_{i, t-1}\right)}\right)\left(\frac{\left(e_{i, t}+e_{i, t-1}\right)}{\sum_{i \in c}\left(e_{i, t}+e_{i, t-1}\right)}\right), \quad k=p, t
$$

and net rates of permanent and temporary employment changes are estimated as

\footnotetext{
${ }^{3}$ The third and fourth years in each ASM panel, for example, have the smallest number of plants meeting the employment history requirement of the low pass filter because in these years the filter requires plants to be present in three, instead of two, consecutive ASM panels.

${ }^{4}$ Because there is a break in the treatment of startups and shutdowns after 1993, I stop my analysis in that year.
} 


$$
N e t_{t}^{c, k}=\sum_{i \in c}\left(\frac{2\left(e_{i, t}^{k}-e_{i, t-1}^{k}\right)}{\left(e_{i, t}+e_{i, t-1}\right)}\right)\left(\frac{\left(e_{i, t}+e_{i, t-1}\right)}{\sum_{i \in c}\left(e_{i, t}+e_{i, t-1}\right)}\right), \quad k=p, t
$$

where $e$ is employment, superscript $k$ denotes either permanent or temporary, subscript $i$ denotes plant $i$, and $c$ denotes continuing plants.

Because of the nature of ASM sampling procedures, it is more likely for large plants to have long uninterrupted time series of employment. Thus, simple aggregations of permanent and temporary employment changes for plants with sufficiently long employment histories may not produce unbiased estimates for the population of manufacturing plants. I attempt to control for this by computing separate estimates for different size plants (the probability of ASM sample selection is inversely proportional to size) and then aggregate these estimates weighting each according to the relevant plant type’s share of aggregate manufacturing employment at continuous plants. Specifically, I compute net and gross rates of employment change for 4 subaggregates: plants with $0<e \leq 50$, plants with $50<e \leq 100$, plants with $100<e \leq 250$, and plants with $e>250$.

$$
\begin{gathered}
\operatorname{gross}_{t}^{c, k}=\sum_{j=1}^{4} \operatorname{gross}_{j, t}^{c, k}\left(\frac{e_{j, t}^{A S M}+e_{j, t-1}^{A S M}}{\sum_{j=1}^{4} e_{j, t}^{A S M}+e_{j, t-1}^{A S M}}\right), \quad k=p, t \\
\operatorname{net}_{t}^{c, k}=\sum_{j=1}^{4} \operatorname{net}_{j, t}^{c, k}\left(\frac{e_{j, t}^{A S M}+e_{j, t-1}^{A S M}}{\sum_{j=1}^{4} e_{j, t}^{A S M}+e_{j, t-1}^{A S M}}\right), \quad k=p, t
\end{gathered}
$$


where subscript $j$ indexes size type, and superscript ASM indicates that $e$ is total employment for the relevant size category in the $A S M .^{5}$

DHS have also used the structure of the LRD to estimate establishment startups and shutdowns. I follow the estimation method outlined in the appendix of DHS and then apply an additional filter described in the appendix to ensure that employment changes caused by startups and shutdowns are long-lasting. One complication is that in the first year of every ASM panel it is difficult to distinguish true permanent shutdowns from plants rotating out of the panel. ${ }^{6}$

Shutdown rates of plants selected with certainty to be in the ASM should not be affected by this problem. To estimate shutdown rates for noncertainty plants, I use a regression of noncertainty plant shutdown rates in years other than first years of ASM panels on the contemporaneous shutdown rate of certainty plants and the net change in employment at continuing plants. ${ }^{7}$

Because my sample of startups and shutdowns includes all startups and shutdowns in the ASM, I use ASM sample weights to compute total permanent shut downs and start ups in every year.

Combining permanent shutdowns and startups with permanent employment changes at continuing plants yields aggregate gross and net rates of permanent job flows.

$$
\begin{gathered}
\operatorname{gross}_{t}^{p}=\operatorname{gross}_{t}^{c, p} \frac{\sum_{i \in c} e_{i, t}+e_{i, t-1}}{\sum_{i \in c \cup s} e_{i, t}+e_{i, t-1}}+\frac{2 *\left(e_{t}^{\text {startup }}+\operatorname{abs}\left(e_{t-1}^{\text {shutdown }}\right)\right)}{\sum_{i \in c \cup s} e_{i, t}+e_{i, t-1}} \\
\operatorname{net}_{t}^{p}=n e t_{t}^{c, p} \frac{\sum_{i \in c} e_{i, t}+e_{i, t-1}}{\sum_{i \in c \cup s} e_{i, t}+e_{i, t-1}}+\frac{2 *\left(e_{t}^{\text {startup }}-e_{t-1}^{\text {shutdown }}\right)}{\sum_{i \in c \cup s} e_{i, t}+e_{i, t-1}}
\end{gathered}
$$

\footnotetext{
${ }^{5}$ An alternative procedure would use ASM sampling weights to aggregate individual plant's permanent and temporary employment changes, but because only 20-25 percent of ASM plants satisfy the employment history requirements of the band-pass filter, these weights are unlikely to be appropriate.

${ }^{6}$ Because there is a CM 2 years prior to the first ASM panel year, one can use a plant's presence in the CM to distinguish plant start-ups from plants rotating into the ASM.

${ }^{7}$ DHS follow a similar procedure when estimating job flows in the first year of ASM panels.
} 
where superscript $s$ denotes permanent shutdowns and startups. Temporary gross and net employment changes for all plants are the same as temporary gross and net employment changes at continuing plants. Details of my procedures for both continuous plants and births and deaths are described in the appendix.

\section{Estimates of Gross and Net Rates of Permanent and Temporary Employment Changes}

The average gross rates of permanent and temporary employment changes reveal the frequencies of these two events and show how important they are to plant-level employment dynamics. The cyclical variation in the rates of net permanent and temporary employment changes shows how important fluctuations in the arrival rate and magnitude of these two types of employment changes are to cyclical movements in aggregate employment.

Table 1 shows average rates of gross permanent and temporary employment changes over the period 1976-1993. The average rate of gross permanent employment changes is 8.8 percent, about 40 percent of the combined gross rates of permanent and temporary employment changes. ${ }^{8}$ Looking within permanent job flows, permanent shutdowns and startups account for approximately 40 percent of total gross permanent employment changes, implying that focusing only on shutdowns and startups when considering permanent changes in employment at the plant level can be misleading. The table also breaks gross permanent job flows into permanent job creation and permanent job destruction and shows that 5.3 percent of all jobs are permanently destroyed each year, while 3.5 percent of all jobs are permanently created. ${ }^{9}$ Analogous figures

\footnotetext{
${ }^{8}$ Because permanent and temporary employment changes may be in opposite directions at continuing plants, the sum of gross permanent and gross temporary employment changes is conceptually greater than or equal to the sum of gross employment changes. Empirically, the difference is small: The sum of gross permanent and gross temporary employment changes exceeds gross employment changes by less than 15 percent.

${ }^{9}$ Permanent job creation is the sum of permanent employment changes across plants with permanent employment in period $t$ greater than permanent employment in period $t-1$ divided by the average of aggregate employment in periods $t$ and $t-1$. Permanent job destruction and temporary job creation and destruction are defined analogously.
} 
for temporary job flows show that an average of 5.0 percent of all jobs are temporarily destroyed each year. Because temporary employment is by definition stationary, close to the same percent of jobs are temporarily created each year, on average.

The table also shows the average rate of excess job flows - the difference between gross and the absolute value of net job flows. This can be interpreted as the component of gross job flows not arising from aggregate shocks, which are assumed to drive net employment changes. Both excess temporary and excess permanent job flows are large—-suggesting that aggregate shocks do not explain the large majority of either type of plant-level job flow. Excess temporary job flows as a share of gross temporary job flows are somewhat larger than permanent excess job flows as a share of gross permanent job flows, suggesting that idiosyncratic shocks are more important as a source of temporary employment changes than of permanent employment changes. I also compute excess job flows at the 2 digit industry level. One can interpret these measures as the amount of industry level gross job flows not due to industry-level shocks. Table 1 shows the average of these industry level excess job flows (weighted by industry employment shares). Again, idiosyncratic shocks (not related to aggregate or industry-level shocks) appear to be the dominant source of both permanent and temporary employment changes.

Next I consider the variation in permanent and temporary employment changes over the business cycle. Figure 1, which plots time series of aggregate rates of net permanent and temporary employment changes shows that both types of employment changes appear to vary cyclically. Table 2 shows average rates of net permanent and net temporary employment changes over expansions and contractions, with expansions defined as periods when aggregate manufacturing employment changes are above average and contractions defined as periods when aggregate manufacturing changes are below average. The latter periods are shaded gray in figure 
1. On average, aggregate manufacturing employment increases by 1.4 percent in expansions and declines by 4.6 percent in contractions. Permanent employment changes account for 42 percent of this difference, while temporary employment changes account for 58 percent. Thus, while both creative destruction and changing utilization are important components of cyclical changes in employment, changing utilization appears to be more important.

Also notable is the fact that permanent and temporary changes in employment are significantly positively correlated: The correlation coefficient is 0.51 and is significant at the 5 percent level. This suggests that they are driven by some common shock and that their similar reactions to this shock act to amplify cyclical changes in employment. Also noteworthy is the fact that changes in both job creation and job destruction, shown in table 2 and figure 2, contribute to cyclical differences in net employment changes for both permanent and temporary employment changes.

Finally, I consider differences across time in the relative importance of permanent and temporary employment changes. Recent research has documented a reduction in the volatility of many important macroeconomic aggregates since the beginning of the 1980s, see Stock and Watson (2002). Table 2 shows that differences in aggregate manufacturing employment changes between recessions and expansions did decrease post 1984. The table also shows that the moderation in cyclical swings in aggregate employment changes owed to moderations in both permanent and temporary employment changes, but that the fluctuation in average net temporary employment changes over the cycle decreased by more. As a share of the fluctuation of total net employment changes over the cycle, net permanent employment changes actually increased. A decomposition of the variance of aggregate employment changes shows that decreases in the variance of temporary employment changes, the variance of permanent employment changes, 
and the covariance between permanent and temporary employment changes contributed 61.9\%, $17.6 \%$ and $20.4 \%$, respectively, to the decline in the variance of total employment changes. These results suggest that, at least in the manufacturing sector, the cause of the decrease in volatility operated across a broad range of economic activity, but was likely more concentrated among factors affecting temporary employment changes.

\section{Do Permanent Employment Changes Create and Destroy Specific Capital?}

Much of the need to distinguish between permanent and temporary employment changes rests on the assumption that a portion of the capital used to permanently create jobs is specific. Under this assumption, the permanent creation and destruction of jobs involves the creation and destruction of specific capital, while the temporary creation and destruction of jobs just alters capital's utilization. ${ }^{10}$ The cost of permanent employment movements would, therefore, be greater, and the economic implications of the two types of employment changes quite different. A simple model of permanent and temporary employment changes suggests a test for the existence of specific capital: If capital is specific, then the response of permanent employment movements to productivity/demand shocks should decline as the capital intensity of a job increases.

\section{Model}

In the model a plant chooses capacity and the utilization of capacity to maximize profits. Output at the plant equals the level of capacity times the level of utilization. Capacity, $n$, is costly to build because much of the capital (physical, organizational, and human) it requires is

\footnotetext{
${ }^{10}$ If firms can only raise utilization by a costly search for suitable employees, then temporary employment changes also create and destroy specific capital. In this case, permanent employment changes would be distinguished by entailing the creation and destruction of significantly more specific capital than temporary employment changes.
} 
specific to the plant. As a result, if a plant decides to destroy capacity, it can only recoup a certain portion of its costs. For simplicity, I assume that this portion is 0 , causing sunk costs to equal the total cost of capacity, $F$. Maintaining its capacity costs the plant $f c$ per unit of capacity every period.

Demand for the plant's product is subject to cyclical and permanent changes. The cyclical portion of demand alternates deterministically between two states: $C^{H}$ and $C^{L}$, with $C^{H}>C^{L}{ }^{11}$ With constant probability $\lambda$ the permanent component of demand, $R$, changes, and the plant's new level of permanent demand is taken from the cumulative probability distribution $H(R)$. These temporary and permanent components of demand shift (multiplicatively) a constant elasticity of demand schedule.

$$
p_{t}=C_{t} R_{t} y^{-\alpha}
$$

where $y$ is output and $p$ is price.

To produce output the plant combines one unit of capacity with one unit of labor, which is available at constant wage rate $w$. The level of labor, $l$, and the level of capacity, $n$, determine the utilization rate, $u$. Output cannot exceed capacity.

$$
\begin{aligned}
& y_{t}=u_{t} n_{t+1}=l_{t} \\
& y_{t} \leq n_{t+1}
\end{aligned}
$$

The plant acts to maximize the present discounted value of profits by choosing a level of capacity and a level of output every period. This decision problem can be represented by the following value function.

\footnotetext{
${ }^{11}$ One could also think of $C$ and $R$ as representing, respectively, temporary and permanent shocks to productivity.
} 


$$
V\left(n_{t}, R_{t}, C_{t}\right)=\operatorname{Max}_{y_{t}, n_{t+1}}\left\{\begin{array}{l}
C_{t} R_{t} y_{t}^{1-\alpha}-w y_{t}-n_{t+1} f_{C}- \\
I^{C}\left(n_{t+1}-n_{t}\right) F+\beta V\left(n_{t+1}, R_{t+1}, C_{t+1}\right)
\end{array}\right\}
$$

subject to

$$
0 \leq y_{t} \leq n_{t+1}
$$

where $I^{c}$ is an indicator function equaling 1 if the value inside the parentheses is greater than 0 and 0 otherwise. The first order conditions characterizing profit maximization are

$$
\begin{aligned}
& (1-\alpha) R_{t} C_{t} y_{t}^{-\alpha}=w+\mu_{t} \\
& \mu_{t}+\beta E \frac{\partial V}{\partial n_{t+1}} \leq F+f c, \text { with equality if } n_{t+1} \geq n_{t} \\
& \mu_{t}+\beta E \frac{\partial V}{\partial n_{t+1}} \geq f c, \text { with equality if } n_{t+1} \leq n_{t} \\
& \mu_{t} \geq 0, n_{t+1}-y_{t} \geq 0, \mu_{t}\left(n_{t+1}-y_{t}\right)=0 \\
& \frac{\partial V}{\partial n_{t}}=\left(I^{C}=1\right) F+\left(I^{C}=0\right)\left(\mu_{t}-f C\right) \leq F
\end{aligned}
$$

where $\beta$ is the discount rate for the firm and $\mu$ is the Lagrange multiplier on the constraint that output cannot exceed capacity. The plant adjusts utilization in response to changes in demand up until the point that capacity is fully utilized or scrapped. The plant adjusts capacity upward only when the marginal benefit of capacity exceeds the sunk cost and maintenance cost and will adjust capacity downward only when the maintenance cost exceeds the current and discounted future profits of the marginal unit of capacity. ${ }^{12}$

If $f_{c}<\beta F$, then capacity will not change in response to cyclical shocks, and one can identify changes in capacity with permanent employment changes. When this condition does not

\footnotetext{
${ }^{12}$ The model implicitly assumes that profits are not dissipated through entry. This assumption is justified if ideas for production processes are not completely imitable. If production processes are completely imitable, then free entry and exit conditions equating profits to entry costs (sunk costs) and exit costs (0), respectively, would determine capacity instead of the marginal value conditions in equations (8). In either case, the model would predict a negative relationship between the level of sunk costs and the frequency of permanent employment changes.
} 
hold, sunk costs are relatively small, and the difference between changes in capacity and changes in utilization are relatively unimportant. As a result, I limit the analysis to the case in which it holds. When $f c<\beta F$, the model predicts a plant will be less likely to increase employment permanently the larger are its sunk costs. To see this, note that these exists an $R, R^{*}$, at which, for given $n_{t}$, the capacity creation condition—the second relationship in (8)—is an equality. Differentiating this condition shows that $\frac{\partial R^{*}}{\partial F}>0$. Thus, the probability of permanently increasing employment— $\operatorname{Prob}\left(R>R^{*}\right)$ — falls as $F$ increases. In addition, since the amount of any job creation is a monotonically increasing function of $\operatorname{Max}\left(0, R-R^{*}\right)$, any permanent increase will be smaller for a given $R$, the greater is $F$. Intuitively, plants with greater sunk costs should be more reluctant to increase capacity.

The model also predicts that permanent job destruction will become less frequent as sunk costs increase. To see this note that there is a level of $R, R^{* *}$, at which, for given $n_{t}$, the capacity destruction condition—-the third relationship of (8)—is an equality. Differentiation of this condition shows that $\frac{\partial R^{* *}}{\partial F}<0$, which says that the probability of permanent job destruction$\operatorname{Prob}\left(R<R^{* *}\right)$-falls as $F$ increases. Also, since permanent job destruction is a positive function of $\operatorname{Max}\left(R^{* *}-R, 0\right)$, at plants where $R$ is low enough to cause permanent job destruction, the amount of permanent job destruction will be lower at plants where $F$ is higher. Intuitively, greater sunk costs increases the value of capital in its current use relative to other options and thus makes plants more reluctant to destroy it. Putting these two results together, the model predicts that gross permanent employment changes should decrease as the level of sunk costs increases. 


\section{Estimation Equations and Results}

To test the predictions of the model, I regress average industry-level gross permanent job flows on measures of the sunk costs of permanent job creation and other determinants of gross permanent job flows. Because sunk costs are not directly observable, I proxy for them using industry-level data on physical capital intensity. Previous research suggests that physical capital intensity is positively correlated with the amount of sunk physical capital per job. Ramey and Shapiro (2001), for example, find that used equipment sells at a considerable discount to its depreciated value. ${ }^{13}$ Because physical capital intensity likely increases with the complexity of production processes, it is also likely positively correlated with human and organizational capital intensity, some of which is also likely to be specific to a plant or industry. ${ }^{14}$ I measure physical capital intensity using the book value of equipment and structures from the CM divided by total employment.

Other factors also likely influence the amount of industry-level gross permanent job flows. DHS show that gross job flows decline with plant age and plant size, as a model of learning about plant specific productivity, e.g. Jovanovic (1982), suggests. To control for this effect, I use the average age and size of plants in an industry. Age and size may also be positively correlated with human and organizational capital, in which case one would expect these variables to be negatively correlated with rates of gross permanent job flows. In addition, to control for the variation in the frequency of idiosyncratic shocks across industries, I also include as a right-hand-side variable the average number of plants sampled in an industry

\footnotetext{
${ }^{13}$ Other authors, e.g. Sutton (1991) and Syverson (2004), have also justified using physical capital as a proxy for the amount of sunk costs. Doms, Dunne and Roberts (1995) find that the probability of plant death is declining in the capital intensity of a plant, a result consistent with sunk costs rising with capital intensity.

${ }^{14}$ Topel (1991), Ruhm (1991), and Neal (1995) show that some human capital is specific to plants or industries, while Rapping (1965) and Bahk and Gort (1993) describe how organizational capital is largely plant specific.
} 
(industries with numerous plants may have a more heterogeneous population). Finally, because large amounts of net permanent employment changes—-such as would be present in trend declining industries, for example-would also be expected to boost average gross employment changes, I also include as a right-hand-side variable the absolute value of an industry's average net permanent employment change. Thus, my estimation equation is

$$
\text { Gross }_{i}^{p}=\alpha+\text { dage }_{i}+\chi \text { size }_{i}+\phi \text { Anet }_{i}+\xi N P_{i}+\gamma C_{i}+\varepsilon_{i}
$$

where all variables are in logs, $i$ indexes four-digit SIC industries, Anet is the absolute value of an industry's average net permanent employment change, $N P$ is the average number of sampled plants in an industry, and $C$ is the log of physical capital intensity. Because there was a break in SIC classification systems between 1986 and 1987, table 3 reports results for two time periods: 1976-1986 and 1987-1993, as well as a combined sample (i.e. the observations were stacked). ${ }^{15}$ I estimate the equation using weighted least squares, where each industry’s observation is weighted by its average number of plants. (Standard errors are estimated using White's robust error method.) The fit of the equation is quite good: $R^{2} \mathrm{~s}$ are around 0.8. As predicted, the coefficients on size and age are significantly negative, and the coefficient on the absolute value of the average net permanent change in employment is significantly positive. Most importantly, the coefficient on capital intensity is significantly negative, implying that the responsiveness of permanent employment to shocks decreases as the amount of physical capital per worker increases. The estimate implies that a ten percent increase in capital intensity decreases the rate of gross job flows by close to one percent. Or put differently, a one standard deviation change in capital intensity across industries results in about a one-quarter standard deviation change in gross permanent job flows. The $t$ statistic is highly significant and serves to reject the hypothesis

\footnotetext{
${ }^{15}$ For the 1976-86 time period, I use the 1977 CM to measure the average capital intensity in an industry. For the 1987-1993 period, I use the 1987 CM.
} 
that sunk costs of permanent job creation are unimportant. The implication is that cyclical movements in permanent job creation and permanent job destruction alter the pace of the creation and destruction of capital with important economic consequences.

The model also implies that the sensitivity of permanent employment changes to increases in specific capital should be greater than the sensitivity of temporary employment changes to increases in specific capital. To test this, I jointly estimate equation (9) and the following equation relating gross temporary job flows to capital intensity and other factors using Zellners’s Seemingly Unrelated Regressions (SUR) technique.

$$
\operatorname{Gross}_{i}^{t}=\alpha+\beta e x_{i}^{p}+\delta_{\text {age }}+\chi \operatorname{size}_{i}+\mu \text { Snet }_{i}+\xi N P_{i}+\gamma C_{i}+\varepsilon_{i}
$$

Snet represents the standard deviation of an industry's net employment changes. If industry conditions are volatile_-as they would be, for example, in cyclically sensitive industries — then one would expect both large swings in net employment changes and high rates of gross temporary employment changes. ex represents the amount by which the sum of Gross $^{\mathrm{p}}$ and Gross $^{t}$ exceeds the gross rate of total job flows (see footnote 8). This may be correlated with larger amounts of temporary job flows if actual permanent changes in employment occur more abruptly than the frequency domain representation of permanent changes supposes. ${ }^{16}$

Estimation results are reported in table 4. Consistent with the model's prediction, the p value for the Wald test of the hypothesis that coefficients on capital intensity are equal in the two equations is 0.0001 for the stacked sample. In sum, these results suggest that permanent changes

\footnotetext{
${ }^{16}$ For example, if a plant reduces employment in period $t$ permanently, the low pass filter would estimate this permanent change as occurring gradually over time. Though the change would be concentrated in period $t$, some of the estimated change would occur before period $t$, and some after period $t$. If permanent employment is decreasing before period $t$, while actual employment is constant, then temporary employment will be increasing. Then, when actual employment drops abruptly in period $t$, temporary employment will decrease and fall below permanent employment.
} 
in plant-level employment involve significantly greater specific capital destruction than temporary employment changes. ${ }^{17}$

Finally, I test whether the effect of capital intensity on gross permanent employment changes is different for births/deaths and permanent changes at continuous plants. Table 5 shows estimates for the following two equations estimated using SUR.

$$
\begin{aligned}
& \operatorname{gross}_{i}^{b d}=\alpha+\text { Sage }_{i}+\chi \text { size }_{i}+\phi \text { Anet }_{i}^{b d}+\xi N P_{i}+\gamma C_{i}+\varepsilon_{i} \\
& \operatorname{gross}_{i}^{p c}=\alpha+\delta \text { age }_{i}+\chi \text { size }_{i}+\phi \text { Anet }_{i}^{p c}+\xi N P_{i}+\gamma C_{i}+\varepsilon_{i}
\end{aligned}
$$

where $b d$ denotes birth/deaths and $p c$ denotes permanent changes at continuous plants. For both types of permanent employment changes, the coefficient on capital intensity is significantly negative. However, the estimate for births/deaths is more negative, and a Wald test of the hypothesis that the two coefficients are equal has a p value of less than 0.0001 for the stacked sample. ${ }^{18}$ This suggests that permanent downsizings and plant expansions create and destroy less specific capital than plant shutdowns and startups.

\section{Conclusion}

Understanding the origins and consequences of business cycles depends, in part, on understanding the relative importance of permanent and temporary employment changes to cyclical fluctuations in employment. If permanent changes in employment are important, then it is important to understand and evaluate the efficiency of the process of creative destruction; see

\footnotetext{
${ }^{17}$ I also test whether the coefficient on capital intensity decreases in absolute value as the frequency of temporary job flows increases. I construct an alternative temporary job flow series with a frequency of less than 4 years. Using this alternative series, the absolute value of the coefficient on capital intensity in the temporary job flows regression decreases and the $\mathrm{p}$ values of Wald tests of no difference between temporary and permanent job flows decrease.

${ }^{18}$ One question raised by these results is why secular increases in capital intensity have not caused a decline in the frequency of permanent employment changes. One possible explanation is that technological change is embodied in capital equipment, see Greenwood, Hercowitz and Krussell (1997). As a result, the cost of capital falls over time as capital intensity increases, leading to no increase in sunk costs measured in terms of consumption goods.
} 
Caballero and Hammour (1996). If temporary employment changes are important, then understanding the efficiency of wage setting and/or the intertemporal elasticity of labor supply (among other factors) is important. Empirically, both types of employment changes appear to be important. While temporary employment changes account for $60 \%$ of the cyclical fluctuation in employment, the across-industry relationship between physical capital intensity and gross permanent employment changes suggests that permanent employment changes create and destroy more capital than temporary job flows, making the economic consequence of their occurrence greater. 


\section{Appendix}

Below I describe the method for estimating permanent employment changes at continuing plants and at startups and shutdowns.

\section{Continuing Plants}

To estimate permanent employment at plant $i$ at time $t$, I use the following backward and forward moving average

$$
e_{i, t}^{p}=\sum_{k=-3}^{3} w_{k} e_{i, t+k}
$$

The weights $w_{k}$ for the moving average are computed using the frequency domain

$$
\begin{aligned}
& w_{k}=\frac{\sin (k \bar{\omega})}{k \pi}+\theta, k=1,2,3 \\
& w_{k}=\frac{\bar{\omega}}{\pi}+\theta, \quad k=0 \\
& \theta=\frac{1-\sum_{k=-3}^{3} \frac{\sin (k \bar{\omega})}{k \pi}}{7}
\end{aligned}
$$

where $\bar{\omega}$ is the cutoff frequency below which a weight of 1 is attached and above which a weight of 0 is attached. Following the recommendation of Baxter and King (1999) I choose

$$
\bar{\omega}=\frac{2 \pi}{8}
$$

which implies that only frequencies with a period greater than 8 years are passed through the filter. For more details on the construction of the weights see Baxter and King (1999).

\section{Shutdowns and Startups}

Shutdowns occur when employment in year $t$ is 0 or missing and employment in year $t-1$ is greater than 0. Following the method of DHS, I use reported ASM coverage codes to distinguish true shutdowns from other events. For example, if the coverage code in year $t$ indicated "plant shutdown", then the event would be treated as a shutdown. On the other hand, if the coverage code in year $t+1$ indicated "plant erroneously deleted in previous year", then the event would not be treated as a shutdown.

Startups are those plants with employment greater than 0 in year $t$ and employment equal to 0 or missing in year $t-1$. In a procedure similar to that described above for shutdowns, coverage code information is used to distinguish true startups from other events. 
The use of coverage codes changed over time. While coverage codes other than 0 ("no change in plant operations”) were used extensively in the 1974-79 ASM panel, subsequently, these codes were used sparingly. I address this break in classification by allowing coverage codes equal to 0 to be consistent with a permanent plant startup in the post 1979 period (but not in the pre 1979 period) provided that other requirements of permanent plant startups are satisfied.

I also apply an additional filter to identify permanent from temporary startups and shutdowns. Specifically, for shutdowns I require that employment in year $t+1$ also be 0 or missing and that employment in the CM that is 2-6 years distant also be 0 or missing. For the first ASM panel year, the CM would be 3 years distant; for the second year, 2 years distant; for the third year, 6 years distant; for the fourth year, 5 years distant; and for the fifth year, 4 years distant. An analogous filter was used to distinguish permanent and temporary startups.

In the first year of ASM panels it is difficult to distinguish permanent shutdowns from plants rotating out of the sample. To estimate death rates in these years, I use plants' levels of employment in the previous CM to identify those plants that are selected with certainty to be in the current ASM (those with employment>250). The death rate I compute for these plants should not be influenced by rotation out of the ASM panel. Next, I regress death rates of noncertainty plants on death rates of certainty plants and the net change in employment at continuing plants, restricting my sample to years other than the first years of ASM panels. I perform the regressions at the 2 digit industry level. I apply the estimated coefficients from these regressions to the death rates of certainty plants and the net growth rates of continuing plants in the first years of ASM panels to estimate the death rates of noncertainty plants in these years. Finally, I add the death rate of certainty to the estimated death rate of noncertainty plants, weighting the rate for each type of plant by the type’s share of aggregate employment. 


\section{References}

Akerlof, George A. and Janet L. Yellen (1990) “The Fair Wage-effort Hypothesis and Unemployment,” The Quarterly Journal of Economics, vol. 105, no. 2, pp. 255-83.

Azariadis, Costas (1975) “Implicit Contracts and Underemployment Equilibia,” Journal of Political Economy, vol. 83, no. 6, pp. 1183-1202.

Bahk, Byong-Hyong and Michael Gort (1993) “Decomposing Learning by Doing at New Plants," Journal of Political Economy, vol. 101, no. 4, pp. 583.

Bailey, Martin Neil (1974) “Wages and Unemployment under Uncertain Demand,” Review of Economic Studies, vol. 41, no. 1, pp. 37-50.

Benhabib, Jess, Richard Rogerson and Randall Wright (1991) "Homework in Macroeconomics: Household Production and Aggregate Fluctuations,” Journal of Political Economy, vol. 99, no. 6, pp. 1166-1187.

Barlevy, Gadi (2001) “Why Are the Wages of Job Changers So Procyclical?” Journal of Labor Economics, vol. 19, no.4, pp. 837-878.

Baxter, Marianne and Robert G. King (1999) “Measuring Business Cycles: Approximate BandPass filters for Economic Time Series," The Review of Economics and Statistics, vol. 81, no. 4, pp. 575-93.

Caballero, Ricardo and Mohamad Hammour (1994) “The Cleansing Effect of Recessions,” American Economic Review, vol. 84, no. 5, pp. 1350-68.

Caballero, Ricardo and Mohamad Hammour (1996) “On the Timing and Efficiency of Creative Destruction,” Quarterly Journal of Economics, vol. 111, no. 3, pp. 805-852. 
Davis, Steven and John Haltiwanger “Gross Job Creation and Destruction: Microeconomic Evidence and Macroeconomic Implications,” NBER Macroeconomics Annual, vol. 5, pp. 123-68.

Davis, Steven, John Haltiwanger, and Scott Schuh. Job Creation and Destruction, Cambridge, MA: MIT Press, 1996.

Doms, Mark, Timothy Dunne and Mark J. Roberts (1995) “The Role of Technology Use in the survival and Growth of Manufacturing Plants,” International Journal of Industrial Organization, Vol. 13, no. 4, pp. 523-542.

Dunne, Timothy, Mark Roberts and Larry Samuelson (1989) “The Growth and Failure of U.S. Manufacturing Plants,” Quarterly Journal of Economics, vol. 104, no. 4, pp. 671-98.

Feldstein, Martin (1976) “Temporary Layoffs in the Theory of Unemployment,” Journal of Political Economy, vol. 84, no. 5, pp. 937-957.

Greenwood, Jeremy, Zvi Hercowitz and Per Krussell (1997) “Long-run Implications of Investment Specific Technological Change,” American Economic Review, vol. 87, no. 3, pp. 342-362.

Hall, Robert E. and Edward P. Lazear (1984) “The Excess Sensitivity of Layoffs and Quits to Demand,” Journal of Labor Economics, vol. 2, no. 2, pp. 233-257.

Jovanovic, Boyan (1982) “Selection and the Evolution of Industry,” Econometrica, vol. 50, no. 3, pp. 649-70.

McDonald, Ian M. and Robert M. Solow (1981) “Wage Bargaining and Employment,” American Economic Review, vol. 71, no. 5, pp. 896-908.

Mortensen, Dale and Christopher Pissarides (1994) "Job Creation and Destuction in the Theory of Unemployment, Review of Economic Studies, Vol. 61, no. 208, pp. 849-919. 
Neal, Derek (1995) “Industry-Specific Human Capital: Evidence from Displaced Workers,” Journal of Labor Economics, Vol. 13, no. 4, pp. 653-677.

Ramey, Garey and Joel Watson (1997) “Contractual Fragility, Job Destruction, and Business Cycles,” Quarterly Journal of Economics, Vol. 112, no. 3, pp. 873-911.

Ramey, Valerie A. and Matthew D. Shapiro (1998) “Displaced Capital: A Study of Aerospace Plant Closings,” Journal of Political Economy, 109, no. 5 (2001): 958-92.

Rapping, Leonard (1965) “Learning and World War II Production Functions,” Review of Economics and Statistics, vol. 47, no. 1, pp. 81-86.

Ruhm, Christopher (1991) “Are Workers Permanently Scarred by Job Displacements?” American Economic Review, vol. 81, no. 1, pp. 319-23.

Stock, James and Mark Watson (2002) “Has the Business Cycle Changed and Why?” NBER Macroeconomics Annual, vol. 17, no. 1, pp. 159-218.

Sutton, John (1990) Sunk Costs and Market Structure, Cambridge, MA: MIT Press.

Syverson, Chad (2004) “Product Substitutability and Productivity Dispersion,” Review of Economics and Statistics, vol. 86, no. 2, pp. 534-550.

Topel, Robert (1991) “Specific Capital, Mobility and Wages: Wages Rise with Job Seniority,” Journal of Political Economy, vol. 99, no. 1, pp. 145-176. 
Table 1. Gross Permanent and Temporary Job Flows (percent)

\begin{tabular}{lccc}
\hline & $1976-1993$ & $1976-1984$ & $1985-1993$ \\
Gross & & Permanent & \\
\cline { 2 - 4 } Job Creation & 8.82 & 8.72 & 8.90 \\
Job Destruction & 3.48 & 3.64 & 3.30 \\
Excess & 5.34 & 5.08 & 5.60 \\
& & & \\
Controlling for 2 & $(0.72$ & 6.83 & 6.61 \\
digit Net Changes & 5.88 & $(0.78)$ & $(0.74)$ \\
& $(0.67)$ & 5.96 & 5.79 \\
& & $(0.68)$ & $(0.65)$ \\
Gross & & & 9.75 \\
Job Creation & 10.32 & Temporary & 4.82 \\
Job Destruction & 5.30 & 10.89 & 4.93 \\
Excess & 5.02 & 5.77 & 8.70 \\
& 8.50 & 5.12 & $(0.89)$ \\
Controlling for 2 & $(0.82)$ & 8.31 & 8.14 \\
digit Net Changes & 8.23 & $(0.76)$ & $(0.83)$ \\
& $(0.80)$ & 8.31 & \\
\hline
\end{tabular}

Note. Numbers in parentheses represent share of relevant gross flow. 
Table 2. Net Job Flows Over the Cycle (percent)

\begin{tabular}{|c|c|c|c|c|c|c|c|c|c|}
\hline & \multicolumn{3}{|c|}{ 1976-1993 } & \multicolumn{3}{|c|}{ 1976-1984 } & \multicolumn{3}{|c|}{ 1985-1993 } \\
\hline & Exp. & Rec. & Diff. & Exp. & Rec. & Diff. & Exp. & Rec. & Diff. \\
\hline Permanent & -0.61 & -3.13 & $\begin{array}{c}2.52 \\
(0.42)\end{array}$ & -0.00 & -3.23 & $\begin{array}{c}3.23 \\
(0.39)\end{array}$ & -1.37 & -3.05 & $\begin{array}{c}1.68 \\
(0.48)\end{array}$ \\
\hline Job Creation & 4.13 & 2.82 & 1.31 & 4.37 & 2.74 & 1.63 & 3.83 & 2.88 & 0.95 \\
\hline Job Destruction & 4.74 & 5.94 & -1.20 & 4.37 & 5.96 & -1.59 & 5.20 & 5.93 & -0.73 \\
\hline Temporary & 2.01 & -1.47 & $\begin{array}{c}3.48 \\
(0.58)\end{array}$ & 2.90 & -2.17 & $\begin{array}{c}5.07 \\
(0.61)\end{array}$ & 0.90 & -0.91 & $\begin{array}{c}1.81 \\
(0.52)\end{array}$ \\
\hline Job Creation & 6.09 & 4.50 & 1.58 & 6.82 & 4.45 & 2.38 & 5.17 & 4.55 & 0.62 \\
\hline Job Destruction & 4.07 & 5.97 & -1.90 & 3.92 & 6.61 & -2.69 & 4.27 & 5.46 & -1.19 \\
\hline
\end{tabular}

Note. Numbers in parentheses represent share of total. 
Table 3. Estimated Coefficients from Regression of Gross Permanent Employment Changes on Capital Intensity by 4 digit SIC Industry

\begin{tabular}{|c|c|c|c|}
\hline Coefficient & 1976-1986 & 1987-1993 & Stacked \\
\hline \multirow[t]{2}{*}{ Constant } & $1.14^{* * *}$ & $0.41^{*}$ & $0.68^{* * *}$ \\
\hline & $(0.19)$ & $(0.22)$ & $(0.14)$ \\
\hline \multirow[t]{2}{*}{ Number of Plants } & $0.02^{* * *}$ & $0.04^{* * *}$ & $0.03^{* * *}$ \\
\hline & $(0.01)$ & $(0.01)$ & $(0.01)$ \\
\hline \multirow[t]{2}{*}{ Age } & $-0.73^{* * *}$ & $-0.43^{* * *}$ & -0.54 \\
\hline & $(0.07)$ & $(0.06)$ & $(0.05)$ \\
\hline \multirow[t]{2}{*}{ Size } & $-0.07^{* * *}$ & $-0.05^{* * *}$ & $-0.06^{* * *}$ \\
\hline & $(0.01)$ & $(0.01)$ & $(0.01)$ \\
\hline Absolute Average Net & $0.31^{* * *}$ & $0.33^{* * *}$ & $0.32^{* * *}$ \\
\hline Permanent Change & $(0.02)$ & $(0.02)$ & $(0.02)$ \\
\hline \multirow[t]{2}{*}{ Capital Intensity } & $-0.07^{* * *}$ & $-0.11^{* * *}$ & $-0.09^{* * *}$ \\
\hline & $(0.01)$ & $(0.01)$ & $(0.01)$ \\
\hline \multirow[t]{2}{*}{1987 dummy } & & & 0.03 \\
\hline & & & $(0.02)$ \\
\hline $\mathrm{R}^{2}$ & 0.77 & 0.80 & 0.78 \\
\hline
\end{tabular}


Table 4. Estimated Coefficients from Regression of Gross Employment Changes on Capital Intensity by 4 digit SIC Industry

\begin{tabular}{|c|c|c|c|c|c|c|c|}
\hline Coefficient & 1976-1986 & 1987-1993 & Stacked & Coefficient & 1976-1986 & 1987-1993 & Stacked \\
\hline \multirow[b]{2}{*}{ Constant } & & Permanent & & \multirow[b]{2}{*}{ Constant } & \multicolumn{3}{|c|}{ Temporary } \\
\hline & $\begin{array}{l}1.15^{* * *} \\
(0.12)\end{array}$ & $\begin{array}{c}10.32^{* * *} \\
(0.46)\end{array}$ & $\begin{array}{c}11.14^{* * *} \\
(0.33)\end{array}$ & & $\begin{array}{l}0.32^{* *} \\
(0.15)\end{array}$ & $\begin{array}{c}-0.22 \\
(1.14)\end{array}$ & $\begin{array}{l}-0.00 \\
(0.01)\end{array}$ \\
\hline $\begin{array}{l}\text { Number of } \\
\text { Plants }\end{array}$ & $\begin{array}{l}0.02^{* * *} \\
(0.01)\end{array}$ & $\begin{array}{l}0.04^{* * *} \\
(0.01)\end{array}$ & $\begin{array}{l}0.03^{* * *} \\
(0.01)\end{array}$ & $\begin{array}{l}\text { Number of } \\
\text { Plants }\end{array}$ & $\begin{array}{l}0.04^{* * *} \\
(0.01)\end{array}$ & $\begin{array}{l}0.06^{* * *} \\
(0.01)\end{array}$ & $\begin{array}{l}0.05^{* * *} \\
(0.01)\end{array}$ \\
\hline Age & $\begin{array}{c}-0.77^{* * *} \\
(0.05)\end{array}$ & $\begin{array}{c}-0.48^{* * *} \\
(0.04)\end{array}$ & $\begin{array}{c}-0.57^{* * *} \\
(0.03)\end{array}$ & Age & $\begin{array}{l}-0.29^{* *} \\
(0.06)\end{array}$ & $\begin{array}{l}-0.15 \\
0.04)\end{array}$ & $\begin{array}{c}-0.19^{* * *} \\
(0.03)\end{array}$ \\
\hline Size & $\begin{array}{c}-0.07^{* * *} \\
(0.01)\end{array}$ & $\begin{array}{c}-0.05^{* * *} \\
(0.01\end{array}$ & $\begin{array}{c}-0.06^{* * *} \\
(0.01)\end{array}$ & Size & $\begin{array}{l}-0.09 \\
(0.01)\end{array}$ & $\begin{array}{c}-0.08^{* * *} \\
(0.01)\end{array}$ & $\begin{array}{c}-0.09^{* * *} \\
(0.01)\end{array}$ \\
\hline $\begin{array}{l}\text { Absolute } \\
\text { Average Net } \\
\text { Permanent } \\
\text { Change }\end{array}$ & $\begin{array}{l}0.27^{* * *} \\
(0.01)\end{array}$ & $\begin{array}{l}0.30^{* * *} \\
(0.02)\end{array}$ & $\begin{array}{l}0.28^{* * *} \\
(0.01)\end{array}$ & $\begin{array}{l}\text { Std. Dev. of } \\
\text { Net } \\
\text { Temporary } \\
\text { Change }\end{array}$ & $\begin{array}{l}0.35^{* * *} \\
(0.01)\end{array}$ & $\begin{array}{l}0.30^{* * *} \\
(0.02)\end{array}$ & $\begin{array}{l}0.33^{* * *} \\
(0.01)\end{array}$ \\
\hline $\begin{array}{l}\text { Capital } \\
\text { Intensity }\end{array}$ & $\begin{array}{c}-0.07^{* * *} \\
(0.01)\end{array}$ & $\begin{array}{c}-0.11^{* * *} \\
(0.01)\end{array}$ & $\begin{array}{c}-0.09^{* * *} \\
(0.01)\end{array}$ & $\begin{array}{l}\text { Capital } \\
\text { Intensity }\end{array}$ & $\begin{array}{l}-0.05^{* * *} \\
(0.01)\end{array}$ & $\begin{array}{c}-0.06^{* * *} \\
(0.01)\end{array}$ & $\begin{array}{c}-0.06^{* * *} \\
(0.01)\end{array}$ \\
\hline 1987 dummy & & & $\begin{array}{l}0.03^{* *} \\
(0.01)\end{array}$ & & & & $\begin{array}{l}0.04^{* * *} \\
(0.01)\end{array}$ \\
\hline $\mathrm{R}^{2}$ & 0.76 & 0.80 & 0.78 & $\mathrm{R}^{2}$ & 0.66 & 0.68 & 0.66 \\
\hline
\end{tabular}

Note. Standard Errors are in parentheses. ${ }^{* * *}$ indicates significance at 1 percent level; ${ }^{* *}$ indicates significance at 5 percent level; * indicates significance at 10 percent level. Coefficients represent elasticities. 
Table 5. Estimated Coefficients from Regression of Gross Permanent Employment Changes on Capital Intensity

\begin{tabular}{|c|c|c|c|c|c|c|c|}
\hline Coefficient & 1976-1986 & 1987-1993 & Stacked & Coefficient & 1976-1986 & 1987-1993 & Stacked \\
\hline & \multicolumn{3}{|c|}{ Births/Deaths } & & \multicolumn{3}{|c|}{ Continuers } \\
\hline Constant & $\begin{array}{l}2.02^{* * *} \\
(0.18)\end{array}$ & $\begin{array}{c}0.75^{\text {*** }} \\
(0.15)\end{array}$ & $\begin{array}{l}1.25^{* * *} \\
(0.11)\end{array}$ & Constant & $\begin{array}{c}-0.71^{* * *} \\
(0 .)\end{array}$ & $\begin{array}{c}-0.86^{* * *} \\
(0.13)\end{array}$ & $\begin{array}{c}-0.85^{* * *} \\
(0.09)\end{array}$ \\
\hline $\begin{array}{l}\text { Number of } \\
\text { Plants }\end{array}$ & $\begin{array}{l}0.09^{* * *} \\
(0.01)\end{array}$ & $\begin{array}{l}0.08^{* * *} \\
(0.01)\end{array}$ & $\begin{array}{l}0.08^{* * *} \\
(0.01)\end{array}$ & $\begin{array}{l}\text { Number of } \\
\text { Plants }\end{array}$ & $\begin{array}{l}0.02^{* *} \\
(0.01)\end{array}$ & $\begin{array}{l}0.02^{* * *} \\
(0.01)\end{array}$ & $\begin{array}{l}0.02^{* * *} \\
(0.01)\end{array}$ \\
\hline Age & $\begin{array}{l}-0.85^{* * *} \\
(0.07)\end{array}$ & $\begin{array}{c}-0.33^{* * *} \\
(0.05)\end{array}$ & $\begin{array}{c}-0.50^{* * *} \\
(0.03)\end{array}$ & Age & $\begin{array}{c}-0.41^{* * *} \\
(0.05)\end{array}$ & $\begin{array}{c}-0.36^{* * *} \\
(0.04)\end{array}$ & $\begin{array}{c}-0.37^{* * *} \\
(0.02)\end{array}$ \\
\hline Size & $\begin{array}{l}-0.09^{* * *} \\
(0.01)\end{array}$ & $\begin{array}{l}-0.02^{*} \\
(0.01)\end{array}$ & $\begin{array}{c}-0.06^{* * *} \\
(0.01)\end{array}$ & Size & $\begin{array}{c}-0.01 \\
(0.01)\end{array}$ & $\begin{array}{l}-0.02 \\
(0.01)\end{array}$ & $\begin{array}{l}-0.01 \\
(0.01)\end{array}$ \\
\hline $\begin{array}{l}\text { Abs. Avg. Net } \\
\text { Permanent } \\
\text { Change } \\
\text { (Births/Deaths) }\end{array}$ & $\begin{array}{l}0.67^{* * *} \\
(0.02)\end{array}$ & $\begin{array}{l}0.81^{* * *} \\
(0.02)\end{array}$ & $\begin{array}{l}0.74^{* * *} \\
(0.01)\end{array}$ & $\begin{array}{l}\text { Abs. Avg. Net } \\
\text { Permanent } \\
\text { Change } \\
\text { (Continuers) }\end{array}$ & $\begin{array}{l}0.25^{* * *} \\
(0.01)\end{array}$ & $\begin{array}{l}0.22^{* * *} \\
(0.01)\end{array}$ & $\begin{array}{l}0.23^{* * *} \\
(0.01)\end{array}$ \\
\hline $\begin{array}{l}\text { Capital } \\
\text { Intensity }\end{array}$ & $\begin{array}{c}-0.08^{* * *} \\
(0.01)\end{array}$ & $\begin{array}{c}-0.10^{* * *} \\
(0.01)\end{array}$ & $\begin{array}{c}-0.09^{* * *} \\
(0.01)\end{array}$ & $\begin{array}{l}\text { Capital } \\
\text { Intensity }\end{array}$ & $\begin{array}{c}-0.04^{* * *} \\
(0.01)\end{array}$ & $\begin{array}{c}-0.04^{* * *} \\
(0.01)\end{array}$ & $\begin{array}{c}-0.04^{* * *} \\
(0.01)\end{array}$ \\
\hline $\mathrm{R}^{2}$ & 0.88 & 0.91 & 0.89 & $\mathrm{R}^{2}$ & 0.58 & 0.60 & 0.59 \\
\hline
\end{tabular}

Note. Standard Errors are in parentheses. ${ }_{* * *}^{* * *}$ indicates significance at 1 percent level; ${ }^{* *}$ indicates significance at 5 percent level; *indicates significance at 10 percent level. Coefficients represent elasticities. 
Figure 1. Net permanent and temporary job flows

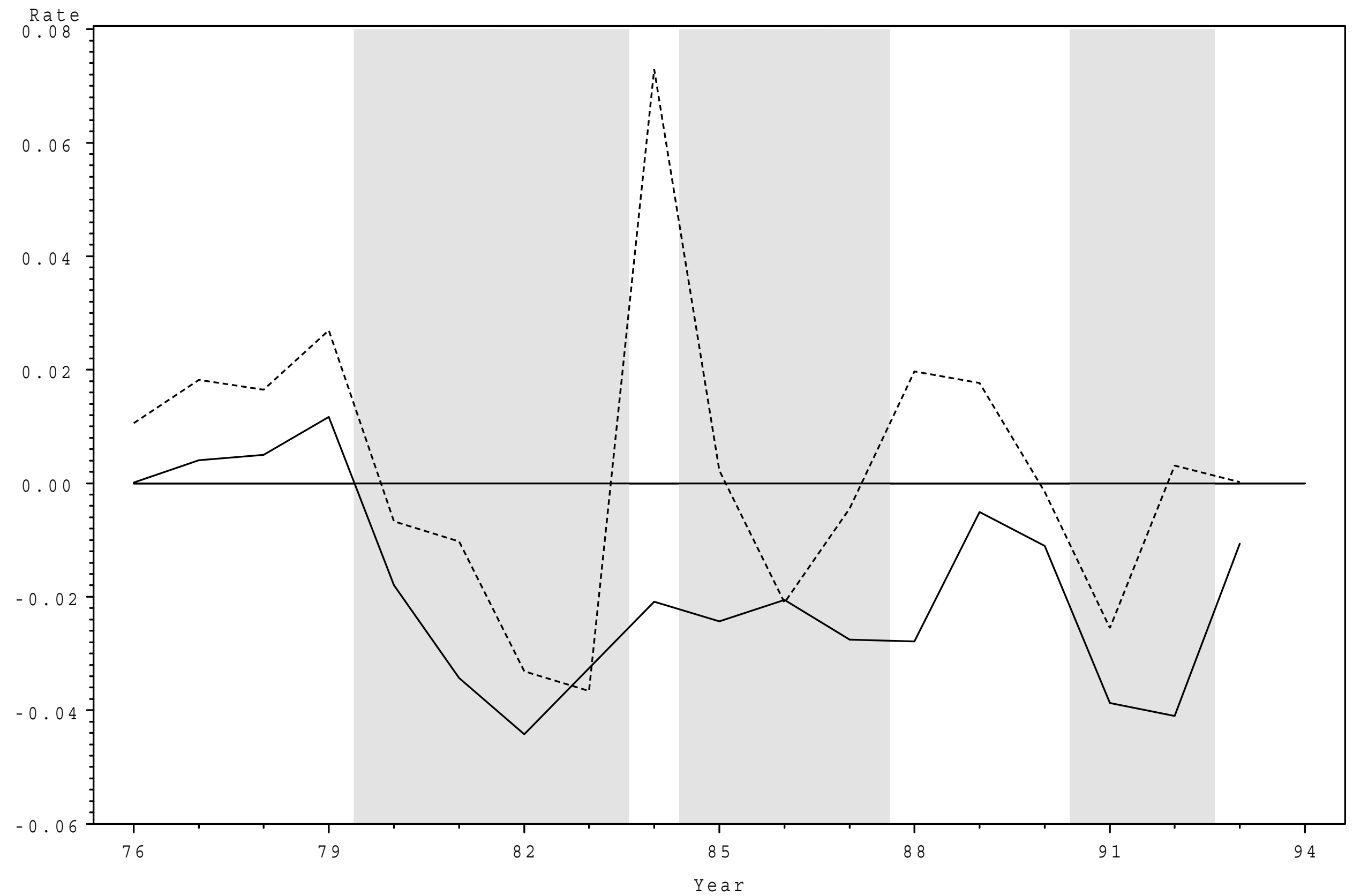

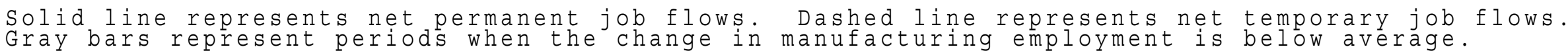




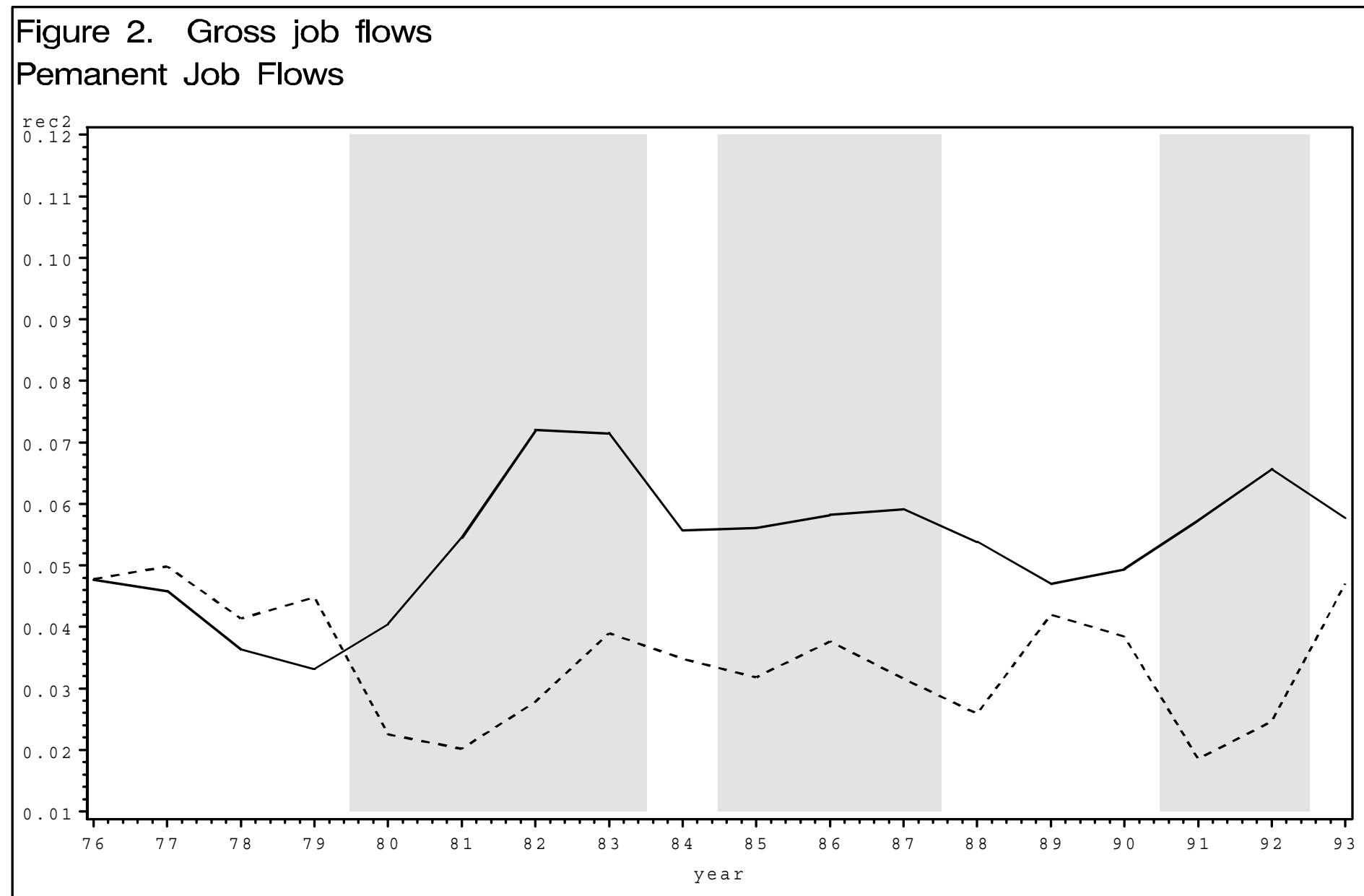

\section{Temporary Job Flows}

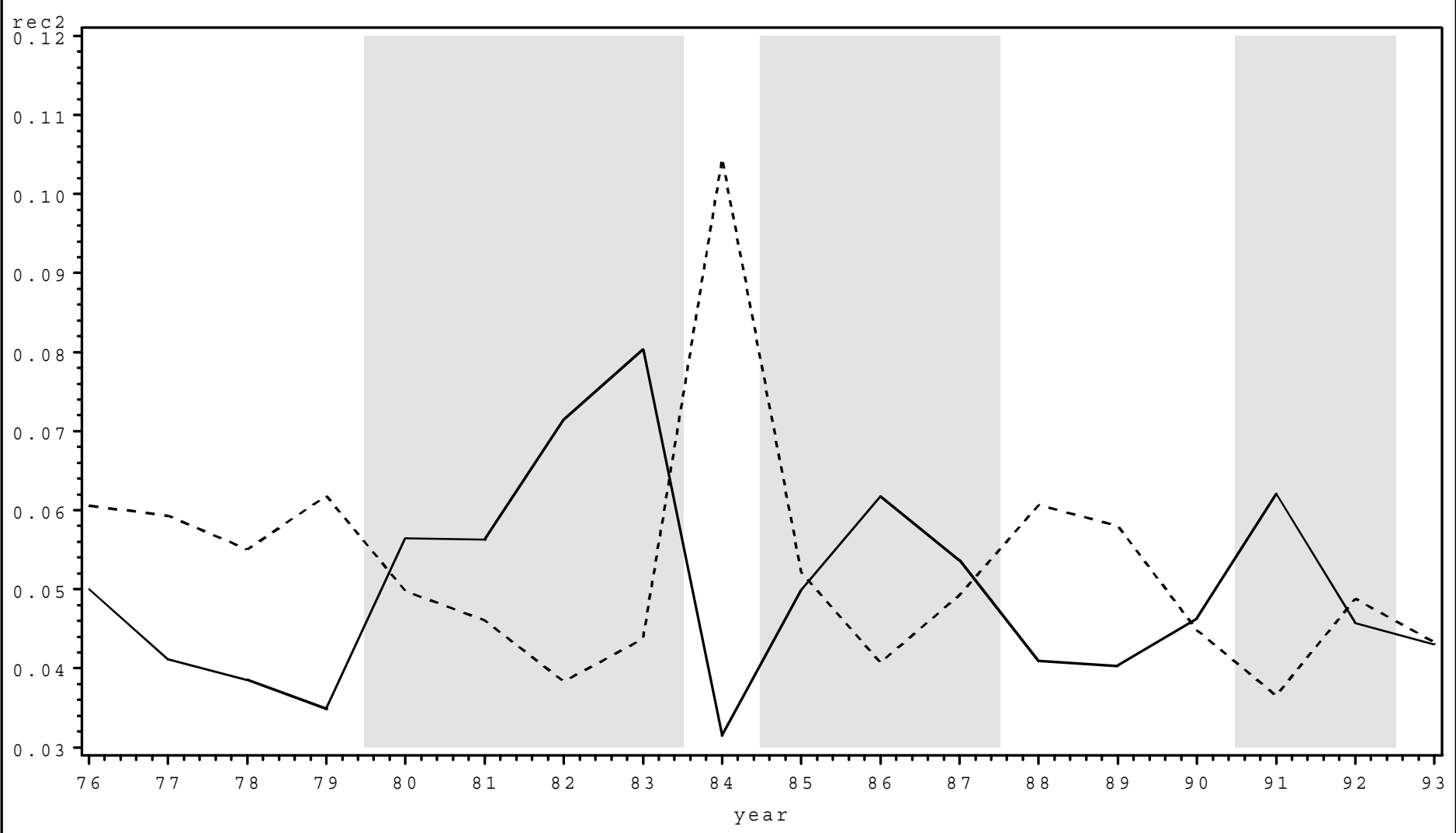

